\section{MP-185 腎移植患者における耐糖能の検討}

大阪市立大学大学院医学研究科泌尿器病態学 ${ }^{1}$ ，大阪市 立総合医療センター ${ }^{2)}$ ，吹田市民病院 ${ }^{3)}$

内田 潤次 ${ }^{1)}$, 長沼 俊秀 ${ }^{1)}$, 町田 裕一 ${ }^{17}$, 北本 興市郎 ${ }^{11}$,

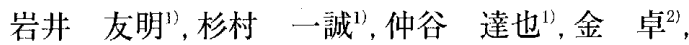

熊田 憲彦-3)

(目的) 腎移植患者に抢ける酎糖能について検討を行う。(刘象と方 法）当院で経過観察中である腎移植後 6 ケをを経過した安定期の患 者のうち原疾患が糖尿病性腎症であった症例、移沭後糖尿病を発症 した症例、空腹時血糖值が $126 \mathrm{mg} / \mathrm{dl}$ 以上の症例を除外した 57 症例 に対し、75g-OGTTを施行し、インスリン抵抗性の指標として HOMA-R、ISI-composite、インスリン分泌能の指標として HOMA$\beta$ 、Insulinogenic index 検討した。 (結果) $75 \mathrm{~g}$-OGTTを施行し た患者の平均年齢は $45.1 \pm 1.7$ (歳)、男女比は $32: 25 、 B M I ~ 21.0 \pm$ $0.5(\mathrm{~kg} / \mathrm{m} 2)$ であった。移植前透析期間は $56.6 \pm 9.1$ (ヶ月)、腎移植 後経過は $95.9 \pm 21.5$ (ヶ月)、カルシニューリン阻害剤は CsA：Tac $31: 26$ であった。 57 症例中 14 例 (24.6\%) で境界型糖尿病と診断さ れた。うち 12 例でWHO の判定区分による impaired glucose tolerance(IGT)を認めた。IGT 群は正常酎糖能群と比較して有意にBMI が高值であり、更に有意な HOMA-Rの上昇、ISI-composite、Insulinogenic index の低下を認めた。 (考察) 腎移植後の耐糖能障害 はインスリン分泌能の低下、インスリン抵抗性の上昇により生じて いることが判明した。IGTは糖尿病発症掞よび心血管系合併症の危 険因子となるため腎移植患者に対して $75 \mathrm{~g}$-OGTTを施行して積 極的に酎糖能障害を早期発見、早期治療が必要である。

\section{MP-186 腎移植症例に発生した悪性腫瘍の検討}

長野赤十字病院泌尿器科1), 大阪大学医学部泌尿器 科2), 井上病院 ${ }^{3)}$

今尾 哲也 ${ }^{1}$, 市丸 直嗣 ${ }^{2}$, 児島 康行 ${ }^{3)}$, 小角 幸人 ${ }^{2)}$, 高原 史郎 ${ }^{2}$, 奥山 明彦 2

【目的】移植患者には健常人より悪性腫瘍の発生が多く、 移植後の免疫抑制剤使用に伴う悪性腫瘍の発症は、重要 な問題である。特に腎移植は長期成績が向上しており、 その発生率が増加している。我々は、当科に扔ける腎移 植後の悪性腫瘍の特徵扔よび悪性腫湯発生の危険因子、 特に免疫抑制剂と悪性腫瘍の関係について検討した。方 法】大阪大学医学部泌尿器科において 1965 年 3 月から 2004 年 4 月 31 日までに腎移植を施行した 556 例を対象 とした。生存率の検討には Kaplan-Meier 法を使用し、各 種の悪性腫瘍の危険因子の多変量解析には、Cox proportional hazard model を使用した。【成績】タクロリムス $(\mathrm{p}=0.0009) 、 \operatorname{MMF}(\mathrm{p}=0.0044)$, basiliximab $(\mathrm{p}=0.0001)$ の使用および移植時年齢 $(\mathrm{p}=0.0358)$ が、単変量解析に おいて有意な危険因子であった。多変量解析においては タクロリムスの使用 $(\mathrm{HR} 4.596, \mathrm{p}=0.0023)$ および移植時 年歯令（HR 1.456, $\mathrm{p}=0.0047 ）$ が有意な独立した危険因子で あった。【結論】タクロリムスの使用および移植時年歯 が、腎移植後の悪性腫瘍発生の危険因子となりうること が示晙された。

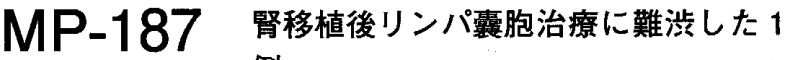 例}

\section{群馬大学大学院医学系研究科泌尿器病態学}

羽鳥 基明, 岡本 亘平, 武智 浩之, 関根 芳岳, 富田 光, 大木 一成, 野村 昌史, 小池 秀和, 曲友弘, 中里 晴樹, 柴田 康博, 伊藤一人, 鈴木 和浩 症例は 30 歳代男性. 腎移植後約 1 力月目に移植腎下部の リンパ震胞 $(3 \times 3$ センチ)による移植腎水腎症が出現し た.リンパ囊胞に対して経皮的エコー下にドレナージ チューブを留置した. ドレナージチューブからのリンパ 液は一日 $600 \mathrm{ml}$ に及んだ。約 1 カ月にわたりエ夕ノール 注入やミノマイシン注入によるリンパ囊胞固定を施行し た結果,リンパ液流出が無くなったためドレナージ チューブを抜去した。 ドレナージチューブ抜去 5 日後の 超音波検查でリンパ囊胞の再発 $(3 \times 3$ センチ) を認めた ため，今度は腹腔鏡下リンパ霊胞開空術を施行した。開 空術に先立ち経尿道的に移植尿管に $6 \mathrm{Fr} の \mathrm{DJ}$ ステント を留置し，その後経皮的エコー下でリンパ䵐胞に $8 \mathrm{Fr}$ の pigtail カテーテルを留置し, これよりインジゴカルミ ン液をリンパ囊胞内に出し入れした．腹腔鏡操作におい て，これらの処置は移植尿管とリンパ囊胞の同定に有用 であった.リンパ囊胞壁を的 2 センチ切開して腹腔内に 開空した，手術後リンパ囊胞の再発は認めていない.

\section{MP-188 神戸大学における小児腎移植臨床統計}

神戸大学大学院腎泌尿器科学 ${ }^{11}$, 兵庫県立尼崎病院泌尿 器科2), 三木市民病院泌尿器科 ${ }^{3)}$, 神戸大学大学院小児 科学 ${ }^{4)}$, 和歌山県立医科大学小児科学 ${ }^{51}$

竹田 雅 ${ }^{11}$, 兵頭 洋二1), 石田 敏郎 ${ }^{1)}$, 原 勲 ${ }^{1)}$,

濱見 学 ${ }^{2}$, 松本 修 $^{37}$, 野津 寛大 ${ }^{4)}$, 吉川 德茂 ${ }^{5 !}$,

藤澤 正人

【目的】過去に当院において経験した小児腎移植の臨床統 計を報告する。【対象】過去 20 年間に当院において 39 例の小児腎移植を施行した。【結果】提供は全例生体腎 かつ血液型適合であり、 pre-emptive 症例は経験してい ない。レシピエントの性別は男児 27 例、女児 12 例。平 均年齢は 11.6 歳で、最小 2 歳 5 か月、手術時最低体重は $11.5 \mathrm{~kg}$ であった。末期腎不全の原疾患は、巣状系球体硬 化症 17 例、低異形成堅 5 例、Alport 症候群 4 例、IgA 腎症 4 例、その他 9 例。ドナーとの関係では親子間が 33 例と大部分を占めた。免疫抑制療法は古典的 3 剂併用が 4 例、シクロスポリンベースが 30 例、夕クロリムスベー スが 5 例。ステロイド長期使用に伴う低身長の傾向を認 めた。移植腎生着率は 1 年 $94.7 \% 、 3$ 年 $92.0 \% 、 5$ 年 $85.6 \% 、 10$ 年 $81.1 \%$ であった。【考察】当院における過 去の成績は概ね良好であった。今後も積極的に小児腎移 植を行っていく予定であり、ステロイドオフや $\mathrm{ABO}$ 不 適合、pre-emptive 症例についても考慮していきたい。 